\title{
Interactions between polymorphonuclear leucocytes, Bacteroides sp, and Escherichia coli: their role in the pathogenesis of mixed infection
}

\author{
WAC VEL, F NAMAVAR, AMJJ VERWEIJ-VAN VUGHT, ANB PUBBEN, \\ DM MacLAREN
}

From the Research Group for Commensal Infections, Vrije Universiteit, Departments of Medical and Oral Microbiology, Amsterdam, The Netherlands

SUMMARY Five Bacteroides fragilis strains and five Bacteroides vulgatus strains were compared with regard to their ability to consume complement and to fix $\mathrm{C} 3$, their killing by polymorphonuclear leucocytes, and their ability to inhibit the bactericidal effect of serum and polymorphs on Escherichia coli strains. Complement consumption was positively related to $\mathrm{C} 3$ fixation, but no relation was observed between these variables and the killing of the anaerobes. Greatest inhibition of the killing of $E$ coli by serum and polymorphs was achieved with the bacteroides strains that fixed most complement. The greater virulence of $B$ fragilis in mixed infections with $E$ coli was not reflected either by a greater ability to inhibit the killing of $E$ coli or a greater resistance of the anaerobes themselves to the bactericidal effect of serum and polymorphs.

A mixture of aerobic and anaerobic bacteria can often be cultured from intra-abdominal infections that are the result of contamination of normally sterile tissues with bacterial flora from the gut. Although it is difficult to tell whether the bacteria cultured are mere contaminants or true pathogens in these infections, abundant evidence shows that combinations of aerobic and anaerobic bacteria acting in synergy are capable of causing infections like (abdominal) abscesses and peritonitis. ${ }^{1-3}$ This synergy between aerobes and anaerobes has been studied extensively in vivo as well as in vitro. ${ }^{4}$

One of the possible explanations of this synergynamely, the impairment of phagocytosis and killing of the aerobes by polymorphonuclear leucocytes in the presence of anaerobes-has been supported by several in vitro studies. ${ }^{5-10}$ These studies show that competition for complement is an important mechanism by which anaerobic bacteria protect aerobic bacteria from killing by polymorphs. To date it is not known whether differences in ability to compete for complement and to inhibit phagocytosis exist between anaerobes that differ in virulence. Furthermore, our attention was drawn to whether or not complement consumption leads to effective opsonisation and killing of the anaerobes. If not,

Accepted for publication 19 December 1986 competition for complement by anaerobes in vivo could lead to a waste of serum factors.

In mixed abdominal infections Bacteroides fragilis is found much more often than Bacteroides vulgatus, the most common bacteroides species in the gut. ${ }^{11}$ In addition, experimental infections in mice have shown that $B$ fragilis is more capable of inhibiting the clearance of $E$ coli than $B$ vulgatus. ${ }^{12}$ In this study we compared the properties of five $B$ fragilis strains and five $B$ vulgatus strains with respect to their consumption of complement, their killing by polymorphs, and their inhibition of the bactericidal effect of serum and polymorphs on $E$ coli strains. Among the strains used were those which showed differences in virulence and synergistic effects in experimental mixed infections with $E$ coli. ${ }^{12}$ The purpose of this study was to discover whether the greater virulence of $B$ fragilis (compared with that of $B$ vulgatus) was reflected in, and possibly explained by, these properties.

\section{Material and methods}

BACTERIA

The Bacteroides strains used in this study were isolated from patients at Vrije Universiteit hospital and $\cong$ identified with Minitek (BBL, Becton Dickinson). $E$ 으 coli $\mathrm{EB} 1 \mathrm{~K}^{-}$was an unencapsulated mutant from $E$ ᄋ 
Table 1 Composition of reaction mixtures in different killing experiments

\begin{tabular}{|c|c|c|c|c|c|c|}
\hline \multirow[t]{2}{*}{ Type of experiment } & \multicolumn{6}{|c|}{ Volume $(\mathrm{ml})$ in reaction mixture } \\
\hline & Polymorphs & Serum* & $\begin{array}{l}\text { Bacteroides treated } \\
\text { serum* }\end{array}$ & Bacteroides & E coli & gel-HBSS \\
\hline $\begin{array}{l}\text { Killing of Bacteroides } \\
\text { Serum sensitivity of Bacteroides } \\
\text { Growth of Bacteroides } \\
\text { Killing of } E \text { coli } \mathrm{EB} 1 \text { : }\end{array}$ & $0 \cdot 5$ & $\begin{array}{l}0 \cdot 1 \\
0 \cdot 1\end{array}$ & & $\begin{array}{l}0 \cdot 1 \\
0 \cdot 1 \\
0 \cdot 1\end{array}$ & & $\begin{array}{l}0.3 \\
0.8 \\
0.9\end{array}$ \\
\hline $\begin{array}{l}\text { In untreated serum } \\
\text { In Bacteroides treated serum } \\
\text { In the presence of Bacteroides }\end{array}$ & $\begin{array}{l}0.5 \\
0.5 \\
0.5\end{array}$ & $\begin{array}{l}0 \cdot 1 \\
0 \cdot 1\end{array}$ & $0 \cdot 2$ & $0 \cdot 1$ & $\begin{array}{l}0 \cdot 1 \\
0 \cdot 1 \\
0 \cdot 1\end{array}$ & $\begin{array}{l}0.3 \\
0.2 \\
0.2\end{array}$ \\
\hline $\begin{array}{l}\text { Serum sensitivity of } E \text { coli } \mathrm{EB} 1 \mathrm{~K}^{-} \text {: } \\
\text { In untreated serum } \\
\text { In Bacteroides treated serum }\end{array}$ & & $0 \cdot 1$ & $0 \cdot 2$ & & $\begin{array}{l}0 \cdot 1 \\
0 \cdot 1\end{array}$ & $\begin{array}{l}0.8 \\
0.7\end{array}$ \\
\hline
\end{tabular}

*The given volumes represent a serum concentration of $10 \%$ in the reaction mixture. In experiments in which other serum concentrations were used the volumes of serum and of gel-HBSS were adjusted.

coli $\mathrm{EB} 1$ which had been isolated from a mixed infection with $B$ fragilis $B E 1$ from a patient in the same hospital. All strains were maintained as a pure culture mixed with $30 \%$ glycerol frozen at $-70^{\circ} \mathrm{C}$

For each experiment strains from the frozen stock were cultured on an agar plate: Bacteroides strains on blood agar base No 2 (Oxoid) supplemented with $5 \%$ sheep blood, $5 \mathrm{mg} / \mathrm{l}$ haemin (BDH, Poole), and $2 \mathrm{mg} / \mathrm{l}$ menadione (Merck, Darmstadt, West Germany) and incubated at $37^{\circ} \mathrm{C}$ in an anaerobic chamber with an atmosphere of $85 \%$ nitrogen, $10 \%$ hydrogen and $5 \%$ carbon dioxide. From these plates single colonies were inoculated in liquid $\mathrm{BM}$ medium, ${ }^{13}$ supplemented with haemin and menadione, and incubated as described above for 18 hours. Log phase cells were obtained by diluting the 18 hour culture $1 / 10$ with fresh medium and growing it until the optical density at $690 \mathrm{~nm}$ reached a value of 0.2 in a Coleman junior 111 spectrophotometer. This value represented $10^{8}$ bacteria $/ \mathrm{ml}$, as determined with a counting chamber (CA Hauser, Philadelphia, United States of America).

$E$ coli was cultured on nutrient agar plates (Blood agar base No 2, Oxoid), and single colonies were inoculated into nutrient broth (Lab Lemco, Oxoid) and grown until in log phase. The cells were harvested by centrifugation, washed three times in phosphate buffered saline ( $\mathrm{pH} \mathrm{7.4)}$ ), counted by viable count, and kept overnight at $4^{\circ} \mathrm{C}$. The next day the suspension was adjusted to a concentration of $10^{8} \mathrm{E}$ coli $/ \mathrm{ml}$.

Bacteroides cells were also harvested by centrifugation and directly resuspended in phosphate buffered saline to a concentration of $10^{8}$ cells $/ \mathrm{ml}$.

\section{SERUM}

In all experiments pooled serum from a large number of healthy donors was used. The serum was kept in aliquots frozen at $-70^{\circ} \mathrm{C}$.

POLYMORPHONUCLEAR LEUCOCYTES

Polymorphs were isolated from the blood of healthy volunteers by dextran sedimentation. The cells were washed three times in Hanks's balanced salt solution (Gibco, New York, United States of America) with $1 \%$ gelatin (gel-HBSS). The cells were counted in a counting chamber, and the suspension was adjusted to $10^{7}$ cells $/ \mathrm{ml}$.

\section{TREATMENT OF THE SERUM WITH \\ BACTEROIDES}

Bacterial suspension $(0.5 \mathrm{ml})$ was mixed with $0.5 \mathrm{ml}$ serum and incubated at $37^{\circ} \mathrm{C}$ in a shaking water bath. For determination of the complement depletion samples were taken after 10,20 , and 30 minutes, immediately cooled in ice, and centrifuged at $7000 \mathrm{~g}$ in a Sarsted MH2 centrifuge at $4^{\circ} \mathrm{C}$ to remove the bacteria. The remaining complement haemolytic activity was determined as described by $\mathrm{Mayer}^{14}$ and expressed as the percentage of the $\mathrm{CH} 50$ value of untreated serum. Serum was also incubated with phosphate buffered saline as a control. Serum that had been incubated for 30 minutes with bacteroides and further treated as described above was used in some experiments for killing as "bacteroides treated serum."

\section{KILLING EXPERIMENTS}

Reaction mixtures were prepared in sterile polypropylene tubes $(12 \times 75 \mathrm{~mm}$, Rofa Mavi, Beverwijk, The Netherlands) and incubated in a Julabo.Paramix shaking apparatus (Rofa Mavi) at $\mathbf{4 0 0} \mathrm{rpm}$ in a carbon dioxide incubator with a humidified atmosphere of $95 \%$ air and $5 \%$ carbon dioxide at $37^{\circ} \mathrm{C}$. Table 1 lists the composition of the reaction mixture in the various experiments.

After $0,30,60$, and 90 minutes $0 \cdot 1 \mathrm{ml}$ of the reaction mixture was suspended in $9.9 \mathrm{ml}$ of distilled water to lyse the polymorphs. Viable counts of the bacteria were carried out by plating serial dilutions on appropriate agar plates. Statistical analysis was performed using the Spearman rank correlation test. 

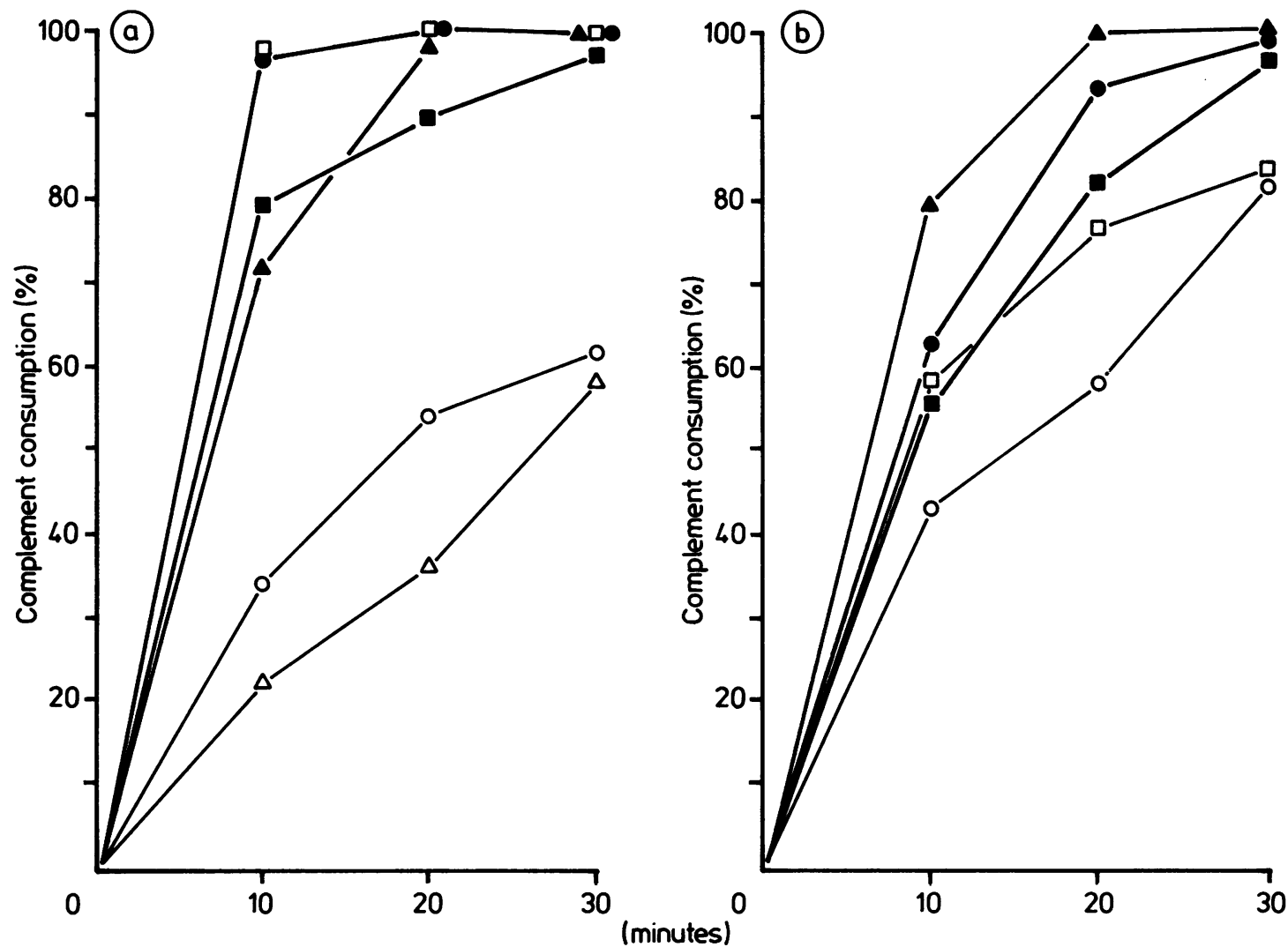

Fig. 1 Complement consumption (\% of CH50 removed by phosphate buffered saline treatment) by E coli EBI and B fragilis strains $(a)$, and by $B$ vulgatus strains $(b)$. Values represent mean of at least three experiments.

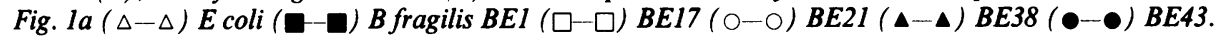

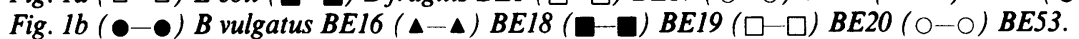

\section{C3 FIXATION BY BACTEROIDES}

Reaction mixtures containing $10^{7}$ Bacteroides and $10 \%$ serum in $1 \mathrm{ml}$ were incubated at $37^{\circ} \mathrm{C}$ in a shaking waterbath for $0,5,15$, and 30 minutes. The $\mathrm{C} 3$ fixation was stopped by adding an equal volume of $12.5 \mathrm{mM}$ cold EDTA (ethylenediamine tetraacetic acid disodiumsalt, Merck) in phosphate buffered saline. The bacteria were washed once in phosphate buffered saline and incubated with $0.5 \mathrm{ml}$ of a $1 / 20$ dilution of fluorescein labelled isothiocyanate conjugated antiserum specific for human $\mathrm{C} 3$ (Wellcome research laboratories, United Kingdom) in phosphate buffered saline at room temperature for 15 minutes. The cells were washed twice in phosphate buffered saline and resuspended in $2.5 \mathrm{ml} 10 \mathrm{mM}$ sodium hydroxide and kept at room temperature for 10 minutes. The bacteria were removed by centrifugation and the fluorescence of the supernatant was determined in a Kontron SFM-23 spectrofluorimeter.
The intensity of the C3 specific fluorescence was shown to be directly proportional to the absolute amount of $\mathrm{C} 3$ fixed on the surface of the bacteria. ${ }^{15}$ The results were expressed as follows. The zero time values for each strain were subtracted from the values obtained at other incubation times. The values thus obtained were expressed as percentage of the $t_{30}-t_{0}$ value of $B$ fragilis BE43.

\section{Results}

\section{COMPLEMENT CONSUMPTION}

Figs. la and $\mathrm{b}$ show the complement consumption by Bacteroides cells when they were incubated with serum. All Bacteroides strains tested consumed serum complement at a faster rate than did $E$ coli EB1 (Fig. 1a). Differences between strains were observed within both species, and no indication was found to suggest that $B$ fragilis strains were more capable of 


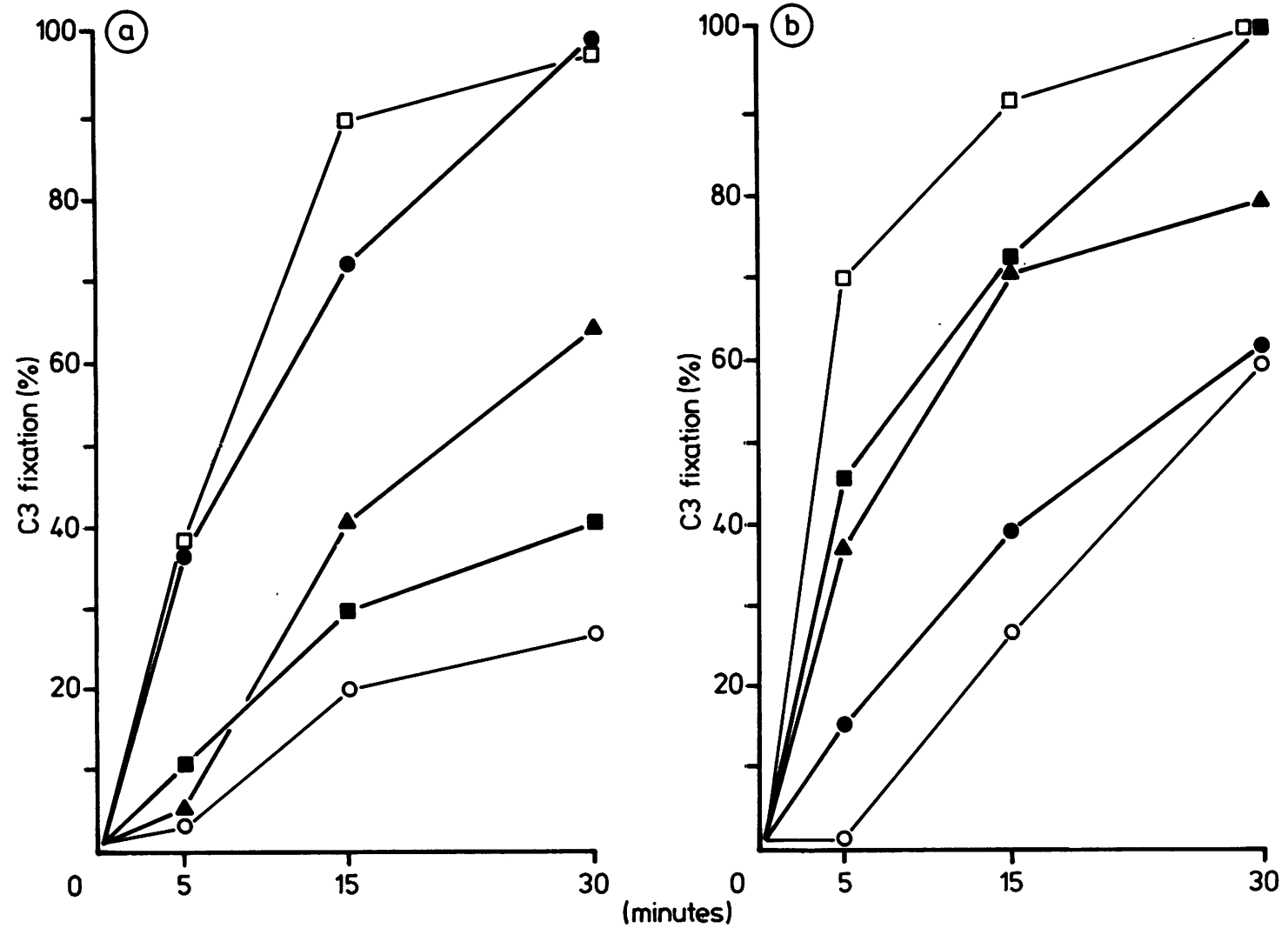

Fig. 2 Complement $C 3$ fixation ( $\%$ of C3 fixed by B fragilis BE43 after 30 minutes) by B fragilis strains (a) and by B vulgatus strains $(b)$. Values represent mean of at least two experiments.

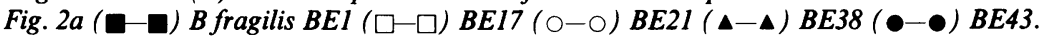

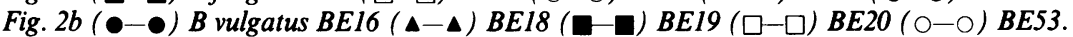

complement consumption than $B$ vulgatus strains.

To find out whether the complement consumed was fixed on the surface of the bacteroides cells or inactivated without being fixed the fixation of $\mathrm{C} 3$ on the surface of the bacteroides cells was measured fluorimetrically. Figs. $2 a$ and $b$ show the results of these experiments with $B$ fragilis and $B$ vulgatus, respectively. Statistical analysis of the relation between complement consumption and $\mathrm{C} 3$ fixation showed a highly positive relation between these variables (Spearman rank correlation test, $p<0.01$ ). We concluded that the Bacteroides strains had removed an equal proportion of the complement consumed by normal fixation of $\mathrm{C} 3$ on their surface.

\section{BACTERICIDAL EFFECT OF SERUM AND}

POLYMORPHS ON BACTEROIDES

Figs. $3 a$ and $b$ show that there were strains which were and were not killed by serum and polymorphs in both species. The 90 minutes of aerobic incubation in these experiments did not kill the anaerobes: when serum and polymorphs were not present viable counts after 30,60 , and 90 minutes did not differ greatly from counts of the original inoculum. Incubation of the bacteria with $10 \%$ serum, but without polymorphs, showed that two $B$ vulgatus strains-namely, BE18 and BE 20-were serum sensitive; all other strains were serum resistant (data not shown). No evidence has been found to suggest that $\boldsymbol{B}$ fragilis was more capable of surviving the bactericidal effects of serum and polymorphs than $B$ vulgatus. Statistical analysis showed no relation between complement fixation and killing or serum sensitivity.

\section{EFFECT OF BACTEROIDES ON THE KILLING OF E COLI EB $1 \mathrm{~K}^{-}$BY SERUM}

$E$ coli $\mathrm{EB} 1 \mathrm{~K}^{-}$was an unencapsuiated mutant of $E$ coli $\mathrm{EB} 1$ and sensitive to the bactericidal action of serum. Table 2 shows the survival of this strain after incubation with various serum concentrations for 60 

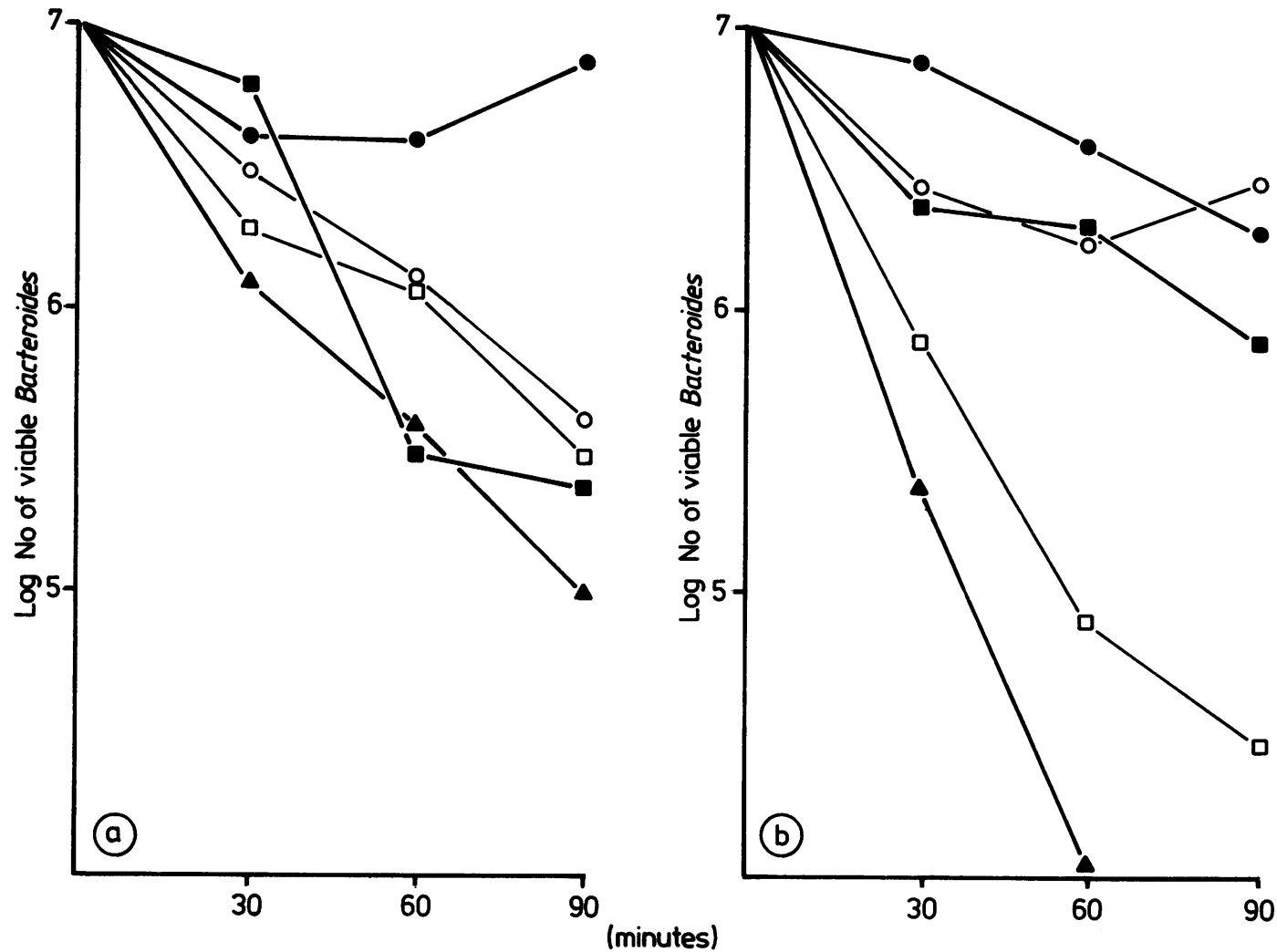

Fig. 3 Killing of $B$ fragilis strains $(a)$ and of $B$ vulgatus strains (b) by polymorphonuclear leucocytes in presence of $10 \%$ pooled normal human serum. Values represent mean of at least three experiments.

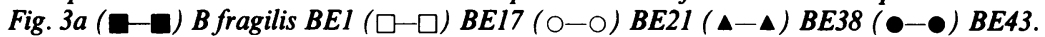

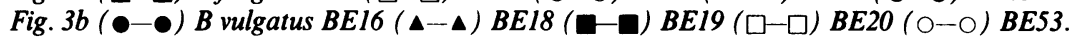

Table 2 Survival of E coli EBI $\mathrm{K}^{-}$in serum pretreated with Bacteroides

\begin{tabular}{llll}
\hline Serum pretreated with & \multicolumn{2}{l}{ Log No of surviving E coli after 60 minutes of incubation in a serum concentration of: } \\
\cline { 2 - 4 } & $1 \%$ & $5 \%$ & $10 \%$ \\
\hline Phosphate buffered saline & $5 \cdot 0$ & $4 \cdot 6$ & $4 \cdot 1$ \\
B fragilis & $7 \cdot 0$ & $5 \cdot 8$ & $5 \cdot 0$ \\
BE1 & $7 \cdot 0$ & $6 \cdot 3$ & $7 \cdot 0$ \\
BE17 & $7 \cdot 1$ & $7 \cdot 1$ & $5 \cdot 1$ \\
BE21 & nd & $7 \cdot 3$ & $7 \cdot 3$ \\
BE38 & nd & $7 \cdot 2$ & $4 \cdot 7$ \\
BE43 & & & $4 \cdot 7$ \\
BElgatus & $7 \cdot 0$ & $6 \cdot 3$ & $5 \cdot 0$ \\
BE18 & $7 \cdot 0$ & $6 \cdot 9$ & $4 \cdot 7$ \\
BE19 & $7 \cdot 0$ & $7 \cdot 0$ & $6 \cdot 3$ \\
BE20 & $7 \cdot 0$ & $7 \cdot 0$ & $4 \cdot 1$ \\
BE53 & $7 \cdot 0$ & $6 \cdot 5$ & 4.4 \\
\hline
\end{tabular}

*Values represent the mean of three experiments. The log number of the inoculum and of $E$ coli surviving in the absence of serum was $7 \cdot 0$. nd: not determined. 
Table 3 Clearance of E coli and Bacteroides sp or Staphylococcus aureus from the skin of mice six days after injection of combinations of these bacteria

\begin{tabular}{|c|c|c|}
\hline \multirow[t]{2}{*}{ Injected bacterial strains (log dose) } & \multicolumn{2}{|c|}{$\begin{array}{l}\text { Log No of bacteria per } \\
\text { lesion }\end{array}$} \\
\hline & E coli & Bacteroides \\
\hline 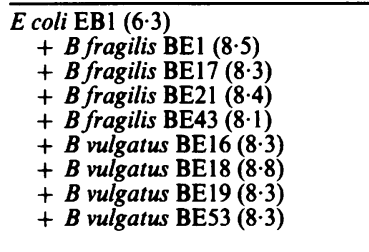 & $\begin{array}{l}1 \cdot 4 \\
4 \cdot 8 \\
2 \cdot 1 \\
5 \cdot 7 \\
5 \cdot 4 \\
2 \cdot 1 \\
3 \cdot 7 \\
6 \cdot 7 \\
2 \cdot 8\end{array}$ & $\begin{array}{l}5 \cdot 0 \\
0 \\
4 \cdot 8 \\
4 \cdot 9 \\
0 \\
1 \cdot 5 \\
6 \cdot 7 \\
0 \cdot 3 \\
\text { Saureus }\end{array}$ \\
\hline $\begin{array}{l}\text { E coli } \mathrm{EB} 1(6 \cdot 7) \\
\quad+S \text { aureus } \mathrm{BE} 50(8 \cdot 6)\end{array}$ & $\begin{array}{l}2 \cdot 4 \\
7 \cdot 6\end{array}$ & $5 \cdot 6$ \\
\hline
\end{tabular}

minutes. Preincubation of the serum with phosphate buffered saline for 30 minutes at $37^{\circ} \mathrm{C}$ did not change the outcome of viable counts, unlike preincubation of the serum with Bacteroides. Whereas 60 minutes of incubation with $1 \%$ untreated, or phosphate buffered saline treated serum reduced the viable count by ca. 2 $\log$, the whole inoculum survived incubation with bacteroides treated serum. Differences in inhibition of the bactericidal effect of serum between strains of Bacteroides were seen at a serum concentration of $5 \%$ or $10 \%$ : at $5 \%$ all strains had some effect, but of varying degrees, and at $10 \%$ only $B$ fragilis BE17, BE38, and BE43 gave complete inhibition.

\section{EFFECT OF BACTEROIDES ON THE KILLING}

OF E COLI EBI BY SERUM AND POLYMORPHS

In the presence of $10 \%$ serum $E$ coli $\mathrm{EB} 1$ was killed by polymorphs: the viable count after 90 minutes was reduced by $1.85 \mathrm{log}$. Ten per cent serum was the minimal concentration required for efficient killing of this strain. When the serum had been pretreated with Bacteroides, or when Bacteroides was present in the reaction mixture, all strains gave complete inhibition of the killing of $E$ coli $\mathrm{EB} 1$. In the presence of $15 \%$ untreated serum the number of $E$ coli was reduced by $1.5 \log$ by polymorphs, but when $B$ vulgatus BE53 or $B$ fragilis BE43 were present in the reaction mixture $1.3 \mathrm{log}$ and $0.9 \log$ of $E$ coli were killed, respectively. Neither BE53 nor BE43 had any inhibiting effect on the killing of $E$ coli in $20 \%$ serum, indicating that enough serum factors remained for the efficient killing of $E$ coli EB1 in this case. Thus differences in inhibiting effect between strains of Bacteroides could be seen only at a serum concentration of $15 \%$ : BE43 had a greater inhibiting effect than BE53, but the difference was small.

When the results of the experiments with $E$ coli $\mathrm{EB} 1$ and $E$ coli $\mathrm{EB} 1 \mathrm{~K}^{-}$were compared with those of the complement fixation experiments it was obvious that the largest inhibiting effect was produced by the best complement fixing strains. Differences in inhibiting effect between Bacteroides strains could, however, be seen only at critical serum concentrations.

\section{Discussion}

The higher incidence of $B$ fragilis in mixed infections with $E$ coli in comparison with other related species like $B$ vulgatus may be explained by a greater virulence of $B$ fragilis, or a greater ability to act in synergy with $E$ coli. Recently, Verweij-van Vught et al ${ }^{12}$ compared four $B$ fragilis strains with four $B$ vulgatus strains with regard to their virulence in monoinfections and mixed infections with $E$ coli. Table 3 shows that three of four $B$ fragilis strains had a greater inhibiting effect on the clearance of $E$ coli than had three of four B vulgatus strains. Staphylococcus aureus also had an inhibiting effect on the clearance of $E$ coli. The authors' study in monoinfections showed that $B$ vulgatus was more rapidly cleared than were $B$ fragilis and $S$ aureus, and, therefore, it was concluded that the inhibiting effect on the clearance of $E$ coli was not specific for $B$ fragilis but could be achieved with organisms which are capable of maintaining themselves in numbers large enough for at least a few days: thus it is a reflection of the virulence in monoinfections.

In this study we compared five $B$ fragilis strains with five $B$ vulgatus strains with regard to their interaction with serum, polymorphs, and $E$ coli in vitro. Among the strains tested were those which had been used by Verweij-van Vught et al. ${ }^{12}$ We compared the complement consumption and $\mathrm{C} 3$ fixation using the two species, their inhibition of the bactericidal effect of serum and polymorphs on $E$ coli, and the killing of the anaerobes themselves by serum and polymorphs. Inhibition of the killing of $E$ coli $\mathrm{EB} 1 \mathrm{~K}^{-}$by serum and that of $E$ coli EB1 by polymorphs was best achieved with the Bacteroides strains which most readily consumed complement. These strains were found within both species.

Differences in inhibition between Bacteroides strains could be observed only at serum concentrations within a narrow range. We found a positive rank correlation between complement consumption and $\mathrm{C} 3$ fixation on the surface of the bacteria but not between these variables and the killing of the anaerobes. Thus it seemed that an equal proportion of the consumed complement was fixed on the surface of the bacteria, by all strains without equally effectively opsonising them. Strains which fixed complement, however, but were not killed subsequently, were found within both species and were not necessarily virulent in vivo. 
To summarise, $B$ fragilis was not more able to resist killing by polymorphs or to protect $E$ coli from killing by serum and polymorphs in vitro by competition for complement than was $B$ vulgatus.

A study of Sundqvist et al ${ }^{16}$ showed that a local shortage of complement can occur in vivo: a pathogenic strain of $B$ gingivalis was injected in subcutaneously implanted teflon cages in guinea pigs. Immunoelectrophoresis of the fluid from the cages showed that complement $\mathrm{C} 3$ was degraded and completely removed by the proteolytic activity of this strain. This study shows that, at least in subcutaneous abscesses, the supply of complement is limited and can be exhausted. Perhaps other organisms can achieve this effect by complement fixation.

Our conclusion, therefore, is that factors other than the ability to act in synergy with $E$ coli by inhibiting its killing, determine the greater pathogenic potential of $B$ fragilis in mixed infections with $E$ coli. Inhibition of the killing of $E$ coli can also be achieved by other complement fixing organisms and may have a role at sites where a local shortage of complement can occur. The ability of these organisms to maintain themselves in numbers sufficient to compete for complement successfully is, however, a prerequisite which $B$ fragilis meets more adequately than does $B$ vulgatus.

\section{References}

${ }^{1}$ Finegold SM. Anaerobic bacteria in human disease. New York: Academic Press, 1977:72-7.

${ }^{2}$ Onderdonk AB, Bartlett JG, Sullivan-Seigler N, Gorbach SL. Microbial synergy in experimental intra-abdominal abcess. Infect Immun 1976;13:22-6.

${ }^{3}$ Kelly MJ. The quantitative and histological demonstration of pathogenic synergy between Escherichia coli and Bacteroides fragilis in guinea pig wound. J Med Microbiol 1978;11:513-25.

${ }^{4}$ MacLaren DM, Namavar F, Verweij-van Vught AMJJ, Vel WAC, Kaan JA. Pathogenic synergy: mixed intra-abdominal infections. Antonie van Leeuwenhoek 1984;50:775-87.

${ }^{5}$ Ingham HR, Sisson PR, Tharagonnet D, Selkon JB, Codd AA. Inhibition of phagocytosis in vitro by obligate anaerobes. Lan- cet 1977;ii:1252-4.

${ }^{6}$ Jones GR, Gemmel CG. Impairment by Bacteroides species of opsonisation and phagocytosis of enterobacteria. J Med Microbiol 1982;15:351-61.

${ }^{7}$ Namavar F, Verweij-van AMJJ, Bal M, van Steenbergen TJM, de Graaff J, MacLaren DM. Effect of anaerobic bacteria on the killing of Proteus mirabilis by human polymorphonuclear leukocytes. Infect Immun 1983;40:930-5.

${ }^{8}$ Wade BH, Kasper DL, Mandell GL. Interactions of Bacteroides fragilis and phagocytes: studies with whole organisms, purified capsular polysaccharide and clindamycin treated bacteria. $J$ Antimicrob Chemother 1983;17 (suppl c):51-62.

${ }^{9}$ Dijkmans BAC, Leijh PCJ, Braat AGP, van Furth R. Effect of bacterial competition in the opsonisation, phagocytosis and intracellular killing of microorganisms by granulocytes. Infect Immun 1985;49:219-24.

${ }^{10}$ Vel WAC, Namavar F, Verweij-van Vught AMJJ, Pubben ANB, MacLaren DM. Killing of Escherichia coli by human polymorphonuclear leucocytes in the presence of Bacteroides fragilis. J Clin Pathol 1985;38:86-91.

${ }^{11}$ Onderdonk AB, Kasper DL, Cisneros RL, Bartlett JG. The capsular polysaccharide of Bacteroides fragilis as a virulence factor: comparison of the pathogenic potential of encapsulated and unencapsulated strains. J Infect Dis 1977;136:82-9.

12 Verweij-van Vught AMJJ, Namavar F, Vel WAC, Sparrius M, MacLaren DM. Pathogenic synergy between Escherichia coli and Bacteroides fragilis and Bacteroides vulgatus in experimental infections: a non-specific phenomenon. J Med Microbiol (in press).

${ }^{13}$ Shah HN, Williams RAD, Bowden GH, Hardy JM. Comparison of the biochemical properties of Bacteroides melaninogenicus from human dental plaque and other sites. J Appl Bacteriol 1976;41:473-92.

${ }^{14}$ Mayer MM. Experimental immunochemistry. Illinois: Charles C Thomas, 1964:149.

${ }^{15}$ Milatovic D, Braveny I, Verhoef J. Clindamycin enhances opsonisation of Staphylococcus aureus. Antimicrob Agents Chemother 1983;24:413-7.

${ }^{16}$ Sundqvist GK, Carlsson J, Herrmann F, Höfling JF, Väätäinen A. Degradation in vivo of the $C 3$ protein of guinea pig complement by a pathogenic strain of Bacteroides gingivalis. Scand J Dent Res 1984;92:14-24.

Requests for reprints to: Dr WAC Vel, Research Group for Commensal Infections, Vrije Universiteit, Departments of Medicine and Oral Microbiology, Amsterdam, the Netherlands. 